Review

\title{
Membranes for Environmentally Friendly Energy Processes
}

\section{Xuezhong He and May-Britt Hägg *}

Department of Chemical Engineering, Norwegian University of Science and Technology, Trondheim NO-7491, Norway; E-Mail: xuezhong.he@chemeng.ntnu.no

* Author to whom correspondence should be addressed; E-Mail: may-britt.hagg@chemeng.ntnu.no; Tel.: +47-735-94033; Fax: +47-735-94080.

Received: 2 August 2012; in revised form: 19 September 2012 / Accepted: 27 September 2012 / Published: 18 October 2012

\begin{abstract}
Membrane separation systems require no or very little chemicals compared to standard unit operations. They are also easy to scale up, energy efficient, and already widely used in various gas and liquid separation processes. Different types of membranes such as common polymers, microporous organic polymers, fixed-site-carrier membranes, mixed matrix membranes, carbon membranes as well as inorganic membranes have been investigated for $\mathrm{CO}_{2}$ capture/removal and other energy processes in the last two decades. The aim of this work is to review the membrane systems applied in different energy processes, such as post-combustion, pre-combustion, oxyfuel combustion, natural gas sweetening, biogas upgrading, hydrogen production, volatile organic compounds (VOC) recovery and pressure retarded osmosis for power generation. Although different membranes could probably be used in a specific separation process, choosing a suitable membrane material will mainly depend on the membrane permeance and selectivity, process conditions (e.g., operating pressure, temperature) and the impurities in a gas stream (such as $\mathrm{SO}_{2}, \mathrm{NO}_{\mathrm{x}}, \mathrm{H}_{2} \mathrm{~S}$, etc.). Moreover, process design and the challenges relevant to a membrane system are also being discussed to illustrate the membrane process feasibility for a specific application based on process simulation and economic cost estimation.
\end{abstract}

Keywords: membrane; $\mathrm{CO}_{2}$ capture; flues gas; natural gas sweetening; biogas upgrading; hydrogen production; VOC recovery; pressure retarded osmosis 


\section{Introduction}

In the International Energy Outlook 2011 (IEO2011) Reference case, world energy consumption is expected to increase by $53 \%$ from 2008 to 2035 [1], and the world energy-related carbon dioxide emissions will rise from 30.2 billion metric tons in 2008 to 35.2 billion metric tons in 2020 , and 43.2 billion metric tons in 2035, followed by a strong economic growth and continued heavy reliance on fossil fuels. Control of anthropogenic emissions of greenhouse gases (GHG) such as $\mathrm{CO}_{2}$ and hydrocarbons (e.g., $\mathrm{CH}_{4}$, and volatile organic compounds (VOC)) is one of the most challenging environmental issues related to global climate change. Reduction of $\mathrm{CO}_{2}$ emissions from large $\mathrm{CO}_{2}$ point sources, especially fossil-fired power plants, based on $\mathrm{CO}_{2}$ capture and sequestration (CCS) technology could be a potential approach for the fight against global warming. The key motivation for $\mathrm{CCS}$ is that fossil fuels can be continuously used without causing significant $\mathrm{CO}_{2}$ emissions, and the captured $\mathrm{CO}_{2}$ could be further processed in different ways, such as injected into oil wells and gas fields for sequestration [2], converted to important products such as methanol [3] or producing third-generation biofuels (algae) based on photosynthesis [4]. Development of renewable energy forms such as wind power, solar energy, hydrogen energy, and biogas may become another feasible option for the reduction of $\mathrm{CO}_{2}$ emissions. Renewable energy is one of the fastest-growing sources for world energy consumption with a $2.8 \%$ increase every year due to the relatively high oil prices, as well as the concern for the environmental impacts of fossil fuel uses and strong government incentives for increasing the use of renewable energy, as reported in IEO2011 [1]. However, in order to satisfy the energy demand for the present and future, the existing alternative energy production technologies must be advanced beyond their current limitations [5], and additional sources of sustainable energy must be explored. Pressure retarded osmosis (PRO) for power generation could be another viable source of renewable energy [6,7]. In addition, the increasing demands of clean and renewable energy have resulted in an increased global willingness to embrace the proposed "hydrogen economy" as a potential long term solution for sustainable development [8].

Membranes are becoming a competitive technology compared to the conventional separation unit operations, e.g., cryogenic distillation, chemical and physical absorption. Membrane gas separation has played an important role in various environmental and energy processes, such as $\mathrm{CO}_{2}$ capture [9-14], VOC recovery [15], natural gas sweetening [16,17], biogas upgrading [18,19], hydrogen production [20-22] during the last two decades, and can potentially compete with some traditional separation methods in terms of energy requirements and economic costs. Different types of membrane materials such as common polymers, microporous organic polymers (MOPs), fixed-site-carrier (FSC) membranes, mixed matrix membranes (MMMs), carbon molecular sieve membranes (CMSMs), as well as inorganic (ceramic, metallic, zeolites) membranes, have been reported to be used in various gas separation processes [9,11,12,14,16,23-31]. Moreover, proton exchange membranes (PEM) electrolyzers have been used for $\mathrm{H}_{2}$ production [32-34]. Recently, pressure retarded osmosis (PRO) technology for power generation (based on knowledge about reverse osmosis (RO)) or forward osmosis (FO) membranes show a great potential for sustainable energy production [35-38]. Figure 1 shows an overview of membrane systems for environmentally friendly energy processes from materials to applications. Choosing a suitable membrane material for a specific application will mainly depend on feed gas composition, process conditions as well the separation requirements. Bernardo et al. 
conducted a review on the status of membrane materials (typically focused on $\mathrm{O}_{2} / \mathrm{N}_{2}, \mathrm{CO}_{2} / \mathrm{N}_{2}$ and $\mathrm{CO}_{2} / \mathrm{CH}_{4}$ membranes), relevant industrial applications, and future opportunities [30]. Their contribution addressed the state-of-the-art materials and the major efforts in the development of the membrane gas separation field. In this paper, an extended review of currently used membrane systems for different applications in energy processes has been conducted, and here we focus more on the challenges, process feasibility and economic costs of membrane gas separations.

Figure 1. An overview of membrane systems used in different energy processes.

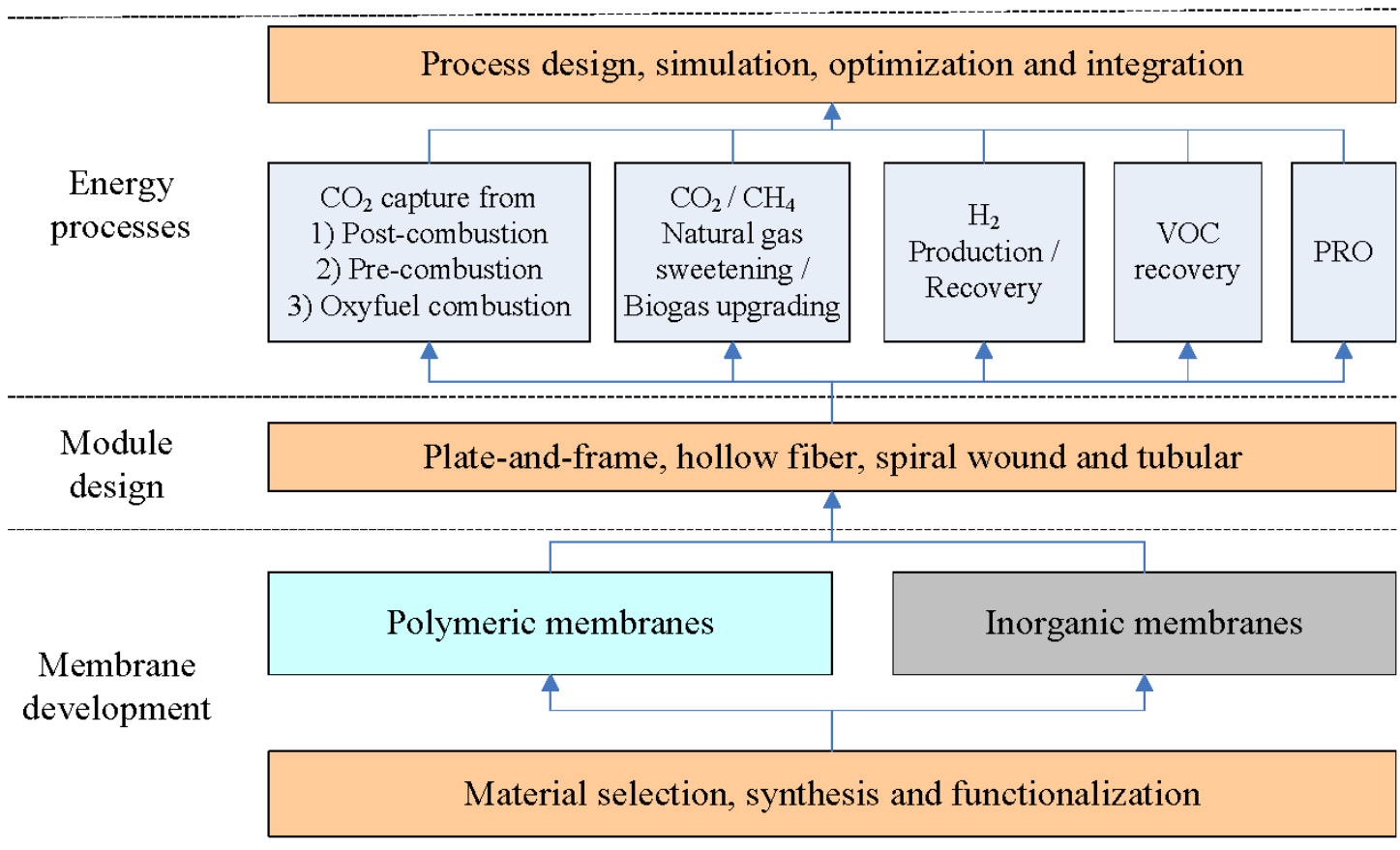

\section{2. $\mathrm{CO}_{2}$ Capture from Power Plants}

The existing fossil fuel power plants for electricity generation without the $\mathrm{CO}_{2}$ capture process could be challenging due to the implication of anthropogenic emissions of $\mathrm{CO}_{2}$ for global warming. A potential solution to reduce $\mathrm{CO}_{2}$ emissions is to develop an efficient $\mathrm{CO}_{2}$ capture technology that can be used to retrofit the existing power plants or design a new combustion process with a high efficiency $\mathrm{CO}_{2}$ capture unit. Carbon capture and sequestration (CCS) could be an effective way to mitigate the emissions of $\mathrm{CO}_{2}$ into atmosphere from fossil fuel power plants, which can be classified as three different scenarios: post-combustion, pre-combustion and oxyfuel combustion as shown in Figure 2 [39].

\subsection{Post-Combustion $\mathrm{CO}_{2}$ Capture}

Different techniques such as chemical absorption (e.g., MEA, MDEA) and physical absorption (e.g., Selexol, Rectisol), physical adsorption (e.g., molecular sieves, metal organic frameworks) and gas separation membranes can be used for $\mathrm{CO}_{2}$ capture from flue gas in post-combustion processes. Membrane separation is energy saving, space saving, easy to scale up, and can be a promising technique for $\mathrm{CO}_{2}$ capture as suggested by Yang et al. [14]. However, there are some challenges related to the potential applications of membrane systems in post-combustion $\mathrm{CO}_{2}$ capture processes as 
summarized in Table $1[10,40]$. According to these challenges, a low cost, highly $\mathrm{CO}_{2}$-permeable, and highly $\mathrm{CO}_{2}$-selective membrane is required for a membrane system to compete with a traditional chemical absorption method. Choosing a suitable membrane material is mainly dependent on the process conditions and separation requirements. If high purity of the product is required, a higher selectivity membrane is preferred. If large gas quantities need to be treated, a high permeance membrane will be preferred.

Figure 2. Three options for $\mathrm{CO}_{2}$ capture from fossil fuel power plants [39].

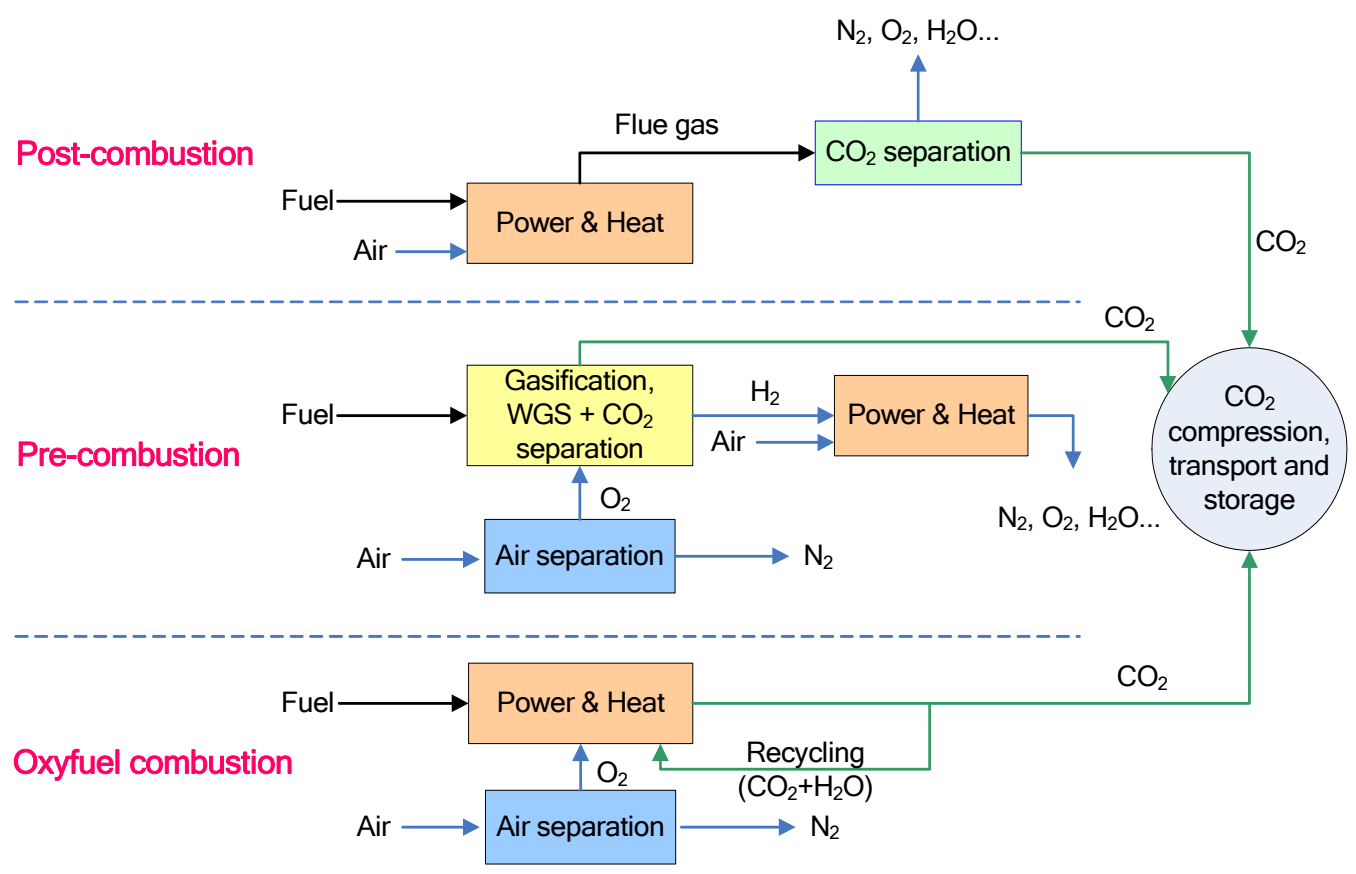

Table 1. Challenges related to standard membrane systems used in post combustion process.

\begin{tabular}{|c|c|c|c|}
\hline $\begin{array}{l}\text { Flue gas } \\
\text { characteristic }\end{array}$ & $\begin{array}{l}\text { Challenges related to membrane } \\
\text { process }\end{array}$ & Potential solution & $\begin{array}{l}\text { Membrane } \\
\text { requirement }\end{array}$ \\
\hline $\begin{array}{l}\text { Low } \mathrm{CO}_{2} \\
\text { concentration }\end{array}$ & $\begin{array}{l}\text { Large quantities of gas need to be } \\
\text { treated }\end{array}$ & Scaling up of membrane unit & $\begin{array}{l}\text { High } \mathrm{CO}_{2} \text { selectivity } \\
\text { and permeance, low } \\
\text { cost }\end{array}$ \\
\hline Low pressure & Low driving force & $\begin{array}{l}\text { Compression in feed or } \\
\text { vacuum in permeate streams }\end{array}$ & $\begin{array}{l}\text { High } \mathrm{CO}_{2} \text { selectivity } \\
\text { and permeance }\end{array}$ \\
\hline $\begin{array}{l}\text { High } \\
\text { temperature }\end{array}$ & $\begin{array}{l}\text { Most polymer membrane cannot } \\
\text { be used at }>100{ }^{\circ} \mathrm{C}\end{array}$ & Cooling down $40-60^{\circ} \mathrm{C}$ & High thermal resistance \\
\hline $\begin{array}{l}\text { Harmful } \\
\text { components } \\
\text { in flue gas } \\
\end{array}$ & $\mathrm{SO}_{2}, \mathrm{NO}_{\mathrm{x}}$ & $\begin{array}{l}\text { Removal of containments or } \\
\text { developing chemically } \\
\text { resistant membranes }\end{array}$ & $\begin{array}{l}\text { High chemical and } \\
\text { aging resistance }\end{array}$ \\
\hline Water & $\begin{array}{l}\text { Water can pass through the } \\
\text { membranes, corrosion of pipeline } \\
\text { during } \mathrm{CO}_{2} \text { transportation }\end{array}$ & Drying of flue gas & $\begin{array}{l}\text { Low } \mathrm{H}_{2} \mathrm{O} / \mathrm{CO}_{2} \\
\text { selectivity }\end{array}$ \\
\hline
\end{tabular}

A large EU project (NanoGLOWA) was launched in 2006, which mainly focused on the investigation of potential membrane materials for $\mathrm{CO}_{2}$ capture from flue gas. The project was based on 
the cooperation between 27 European companies, universities, institutes and power plants (www.nanoglowa.com), and in 2011, two small pilot-scale membrane modules were installed at EDP's power plant in Sines (Portugal) and EON's power plant in Scholven (Germany) to demonstrate the potential of $\mathrm{CO}_{2}$ capture using polymeric membranes. The testing in Portugal was performed over $\sim 6$ months, and separation properties and durability of the fixed-site-carrier (FSC) membranes were demonstrated in an actual flue gas stream. The performance of this FSC-membrane has since then been greatly improved with a permeance of $\sim 5 \mathrm{~m}^{3}(\mathrm{STP}) /\left(\mathrm{m}^{2} \mathrm{~h}\right.$ bar), and selectivity $\mathrm{CO}_{2} / \mathrm{N}_{2}>1000$ [41].

Many research activities on the investigations of different membranes for $\mathrm{CO}_{2}$ capture have been conducted, some examples are given in [9-14]. He et al. investigated the application of hollow fiber carbon membranes for $\mathrm{CO}_{2}$ capture from flue gas [28,42-44]. They reported a capital cost of 100 \$/tonne $\mathrm{CO}_{2}$ avoided using carbon membrane [42], which is still higher than traditional chemical absorption method of MEA (59 \$/tonne $\mathrm{CO}_{2}$ avoided reported by Rao and Rubin [45]), but the referred carbon membranes had a clear potential for further optimization. Merkel et al. [46] reported that a membrane with a $\mathrm{CO}_{2} / \mathrm{N}_{2}$ selectivity above 50 and a 4000 GPU permeance $\left(1 \mathrm{GPU}=2.736 \times 10^{-3} \mathrm{~m}^{3}(\mathrm{STP}) /\left(\mathrm{m}^{2} \mathrm{~h}\right.\right.$ bar $\left.)\right)$ could offer a capture cost below $15 \$ /$ tonne $\mathrm{CO}_{2}$, which is lower than the US Department of Energy's (DOE) target of $20 \$$ tonne $\mathrm{CO}_{2}$ [47]. Their innovative process solution to the $\mathrm{CO}_{2}$ capture is also contributing strongly to their conclusion where they also pointed out that improving membrane permeance is more important than increasing selectivity (given selectivity is $>30$ ) in order to further reduce the membrane unit's cost. Hussain et al. conducted a feasibility analysis by HYSYS integrated with an in-house membrane program (ChemBrane, developed by Grainger [48]) to investigate the influence of process parameters on energy demands and cost using a novel $\mathrm{CO}_{2}$-selective FSC membrane [13]. Their results indicated that a membrane system using high performance FSC membranes was feasible for $\mathrm{CO}_{2}$ capture, even at a low $\mathrm{CO}_{2}$ concentration $(\sim 10 \%)$ in a flue gas, compared to amine absorption in terms of energy requirement, and it was also possible to achieve more than $90 \% \mathrm{CO}_{2}$ recovery and $>95 \% \mathrm{CO}_{2}$ purity in permeate stream. In any case, this environmentally friendly technology with improved membrane performance could promote membrane systems as a promising candidate for $\mathrm{CO}_{2}$ capture from flue gas in post-combustion process if all the challenges (shown in Table 1) can be well addressed.

Liquid membranes have also been investigated for $\mathrm{CO}_{2}$ separation [49-53], and most of these works use non-volatile liquids of room temperature ionic liquids (RTILs) as the carriers to transport $\mathrm{CO}_{2}$. A review on the development of liquid membranes for gas/vapor separation has been conducted by Krull et al. [54]. They pointed out that the use of ionic liquids could improve the liquid membrane stability. However, ionic liquids are still in a minority and not commercially available. Another challenge of liquid membranes is the lack of long-term stability when faced with $\mathrm{CO}_{2}$ capture in industrial application. Membrane contactors, which combine gas separation membranes and solvents, offer a unique way to perform gas-liquid absorption and provide high operational flexibility [55]. There has been strong interest focused on the improvement of membrane contactor efficiency for $\mathrm{CO}_{2}$ capture [55-62]. Yeon et al. [60] reported the use of a polyvinylidene difluoride (PVDF) hollow fiber membrane contactor for absorption and a stripper column as desorber for $\mathrm{CO}_{2} / \mathrm{N}_{2}$ separation, which presented a higher $\mathrm{CO}_{2}$ removal efficiency than the conventional absorption column. Feron et al. have investigated the potential application of $\mathrm{CO}_{2}$ capture from flue gas using a membrane contactor composed of porous polypropylene hollow fiber membranes and a dedicated absorption liquid 
(CORAL) [59]. Their results indicated that a membrane contactor could be an interesting candidate for $\mathrm{CO}_{2}$ capture from flue gas in post-combustion power plants. In conclusion, for post-combustion $\mathrm{CO}_{2}$ capture, the indications are that the only membranes which will have a potential of being economically viable will need to be polymers with high flux, and moderate to high selectivity $\left(\mathrm{CO}_{2} / \mathrm{N}_{2}\right)$ and can tolerate impurities such as $\mathrm{SO}_{2}, \mathrm{NO}_{\mathrm{x}}$ and $\mathrm{H}_{2} \mathrm{O}$. The new membrane contactors containing stable carriers are also promising candidates. Innovative energy-saving process solutions will likewise help to promote membranes for this application.

\subsection{Pre-Combustion $\mathrm{CO}_{2}$ Capture}

Pre-combustion $\mathrm{CO}_{2}$ capture is often referred to as $\mathrm{CO}_{2} / \mathrm{H}_{2}$ separation at high temperature and pressure. Both $\mathrm{CO}_{2}$-selective and $\mathrm{H}_{2}$-selective membranes can be used for this application. For a $\mathrm{CO}_{2}$-selective membrane, $\mathrm{H}_{2}$ will be kept in the retentate stream with high concentration and pressure, and can be directly combusted in the turbine. While for $\mathrm{H}_{2}$-selective membranes, $\mathrm{CO}_{2}$ will remain in the retentate stream with high pressure and can be conveniently compressed for transportation and storage. While a $\mathrm{CO}_{2}$-selective membrane at high temperature is rare for this gas pair, several $\mathrm{H}_{2}$-selective membranes have been widely investigated. Membrane is then usually integrated with water-gas shift (WGS) reaction as a membrane reactor for driving the production of $\mathrm{H}_{2}$. Scholes et al. conducted a comprehensive review on membranes for $\mathrm{CO}_{2}$ capture from pre-combustion processes [63]. They reviewed various types of membranes and membrane reactors as well as membrane processes and economics. Here we mainly have focused on the process feasibility of different membranes for pre-combustion $\mathrm{CO}_{2}$ capture.

Choosing a suitable membrane material is mainly dependent on process design, operating conditions, and the location of a membrane system in a pre-combustion process since each type of membrane material has its own optimal operating temperature range and limitations. Palladium (Pd) membrane is typically used for $\mathrm{H}_{2}$ separation and purification in combination with a reactor in water gas shift (WGS). Pd-membrane has an extremely high selectivity for $\mathrm{H}_{2}$ over the other gas molecules. However, Pd membranes may suffer poisoning problems due to interactions with sulfur compounds, $\mathrm{CO}$ and unsaturated hydrocarbons which are present in syngas of pre-combustion processes. Some $\mathrm{Pd}$-alloys such as $\mathrm{Pd}-\mathrm{Au}$ and $\mathrm{Pd}-\mathrm{Cu}$ membranes have been developed and showed more resistance to sulfur poisoning $[64,65]$. Pd membranes also undergo phase change below their critical point of $571 \mathrm{~K}$ and $2 \mathrm{MPa}$ leading to boundary defects and hydrogen embrittlements [66], which can be partly reduced by adding some other metals, such as $\mathrm{Ag}, \mathrm{Cu}$, or Ni. Another challenge of Pd membranes is their short lifetime under harsh conditions, which may hinder their commercial applications $[63,66]$.

Ceramic membranes can also be used for high temperature applications, especially in the chemically aggressive environment of a pre-combustion process. However, the main challenge of ceramic membranes is the stability of the selective layer in a hot stream. Polybenzimidazole (PBI) is a thermally stable polymer with a reported glass transition temperature of $420{ }^{\circ} \mathrm{C}$, and PBI-based membranes can be operated at high temperature $\left(200-400{ }^{\circ} \mathrm{C}\right)$. Krishnan et al. [67] conducted process simulation of $\mathrm{CO}_{2}$ capture from syngas using $\mathrm{H}_{2}$-selective $\mathrm{PBI}$ membranes in an integrated gasification combined cycle (IGCC) process. They simulated four scenarios including IGCC without $\mathrm{CO}_{2}$ capture (scenario 1), $\mathrm{CO}_{2}$ capture using Selexol (scenario 2), $\mathrm{CO}_{2}$ and $\mathrm{H}_{2} \mathrm{~S}$ capture using PBI membranes 
(scenario 4A), $\mathrm{CO}_{2}$ capture using PBI membranes and $\mathrm{H}_{2} \mathrm{~S}$ capture using Selexol (scenario $4 \mathrm{~B}$ ). A $\mathrm{CO}_{2}$ avoidance cost of $39 \$ /$ tonne $\mathrm{CO}_{2}$ was found for scenario $4 \mathrm{~A}$ to attain $90 \% \mathrm{CO}_{2}$ removal, which is much lower compared to the other scenarios (scenario 2 and scenario $4 \mathrm{~B}$ are 50 and $54 \$$ tonne $\mathrm{CO}_{2}$, respectively) reported in their simulation results.

A highly selective $\mathrm{CO}_{2} / \mathrm{H}_{2}$ facilitated transport membrane in an IGCC power plant was also investigated by Grainger et al. [68]. Their membranes comprised a thin polyvinylamine (PVAm) selective layer coated on a ultrafiltration (UF) polysulfone support, which showed a superior separation performance with a $\mathrm{CO}_{2}$ permeance of $0.1 \mathrm{~m}^{3}(\mathrm{STP}) /\left(\mathrm{m}^{2} \mathrm{~h}\right.$ bar), and $\mathrm{CO}_{2} / \mathrm{H}_{2}$ selectivity over 100 , based on the mixed gas tests. Their simulation results indicated that the modified process with sour shift process could achieve $85 \% \mathrm{CO}_{2}$ removal at an acceptable purity for sequestration. The plant cost was calculated to be $2320 € / \mathrm{kW}$ with an electricity production cost of $7.6 €$ cents $/ \mathrm{kWh}$ and a $\mathrm{CO}_{2}$ avoidance cost of $39 € /$ tonne $\mathrm{CO}_{2}$. The gas separation performance of these FSC membranes has lately been significantly improved as documented in [41] (with a high $\mathrm{CO}_{2}$ permeance $\sim 5 \mathrm{~m}^{3}(\mathrm{STP}) /\left(\mathrm{m}^{2} \mathrm{~h}\right.$ bar) and a selectivity $>1000$ for $\mathrm{CO}_{2} / \mathrm{N}_{2}$ ), which indicates that the mechanically stronger PVAm/PVA blend FSC membranes could become a promising candidate for pre-combustion $\mathrm{CO}_{2}$ capture where pressure is high if the operating temperature can be brought down.

\subsection{Oxyfuel Combustion $\mathrm{CO}_{2}$ Capture}

Oxyfuel (oxygen-enriched) combustion technology provides a promising option based on the combustion using high purity $\mathrm{O}_{2}$ produced from an air separation unit (ASU), thus resulting in a flue gas containing mostly $\mathrm{CO}_{2}$ and water. Water can then be easily removed via condensation, thereby generating high purity $\mathrm{CO}_{2}$ for transportation and storage. One challenge for oxyfuel combustion process is the high combustion temperature with rich $\mathrm{O}_{2}$. Habib et al. reported to recycle part of flue gas back into the combustion chamber to moderate the combustor temperature [69]. Another challenge is to get the high purity $\mathrm{O}_{2}$ source to make oxyfuel combustion process as a competitive $\mathrm{CO}_{2}$ capture technology. Conventional $\mathrm{O}_{2}$ purification is currently utilizing cryogenic distillation which is an energetically expensive process. An alternative way is to use a membrane system, in which high purity $\mathrm{O}_{2}$ can be produced by a two-stage membrane unit. Strong interests have been focused on the development of new membrane materials with high $\mathrm{O}_{2}$ permeance and selectivity $\left(\mathrm{O}_{2} / \mathrm{N}_{2}\right)$ to produce high purity oxygen from air using a single stage membrane unit. Ceramic membranes made from mixed ion-electronic conducting oxides (high temperature ion transport membrane (ITM) [70,71]) have received increasing attention because of their potential to reduce the cost of $\mathrm{O}_{2}$ production, which could promote the development of this clean energy process. A commercial ITM membrane module for pure $\mathrm{O}_{2}$ production from air has been developed by Air Products [72]. Their ITM oxygen unit can attribute a $48 \%$ less capital cost and a $68 \%$ energy saving compared to cryogenic ASU. Moreover, pressurized oxyfuel combustion systems could be another potential solution to achieve a high purity $\mathrm{CO}_{2}$ in flue gas and reduce the energy penalties, which provides a better performance over conventional atmospheric oxyfuel combustion power cycles [73,74]. CANMET Energy Technology Centre and ThermoEnergy Corp. have conducted the techno-economic evaluations on the pressurized oxyfuel combustion systems [75-77]. Their results showed an improved net efficiency and the reduction of capital and electricity costs using high pressure oxyfuel combustion technology. The 
oxyfuel combustion is a very smart way of capturing $\mathrm{CO}_{2}$. The main challenge, however, seems to be the development of a good module and sealing design based on the ceramic oxides which can tolerate the high operating temperatures without leakage and cracks.

\section{Natural Gas Sweetening}

$\mathrm{CO}_{2}$ removal from natural gas (natural gas sweetening) is mandatory to meet the specifications of a natural gas grid since $\mathrm{CO}_{2}$ reduces the heating values of natural gas, is corrosive, and easily forms hydrates to clog equipment or damage pump [30]. Choosing a suitable technology for $\mathrm{CO}_{2}$ removal from natural gas is mainly dependent on process conditions and crude natural gas composition. Traditional chemical (amine) absorption is well known and has been commercially used for $\mathrm{CO}_{2}$ removal in various processes, and is still considered as a state-of-the-art technology. However, a membrane system possesses many advantages such as small footprint, low capital and operating costs, is environmentally friendly and exhibits process flexibility [29]. It shows a great potential for natural gas sweetening even though it has only $5 \%$ of the market today. Two key parameters - membrane unit cost and $\mathrm{CH}_{4}$ loss - are mainly dependent on the membrane performance and process design, which are usually employed to evaluate the efficiency of a membrane process. Cellulose acetate is still widely used in UOP's membrane system [16] and, recently, Cynara-NATCO installed a cellulose triacetate membrane system using 16-inch hollow fiber modules in Thailand [78]. Although common polymer membranes for natural gas sweetening are still using cellulose acetate/triacetate and polyimide, the novel, high performance composite FSC membranes showed great potential for $\mathrm{CO}_{2} / \mathrm{CH}_{4}$ separation [79]. Membrane systems are preferred for high $\mathrm{CO}_{2}$ concentration gas streams (enhanced oil recovery, ca. $50 \% \mathrm{CO}_{2}$, and high pressure) and amine units are preferred for relatively low-concentration gas streams. Moreover, membrane systems are also favorable for processing small gas flows (typically for offshore platforms, $<6000 \mathrm{Nm}^{3} / \mathrm{h}$ ) because of their simple flow schemes, while amine units are more complex and require careful, well-monitored operating procedures, as documented by Baker et al. [16].

High pressure operation is the main challenge for natural gas processing with membrane systems. Plasticization is indeed always a limited factor for high pressure $\mathrm{CO}_{2}$ rich gas to be separated with membranes [80,81], while for FSC membranes, carrier saturation at a high $\mathrm{CO}_{2}$ concentration and low water content in high pressure feed gas stream cause a significant decrease of $\mathrm{CO}_{2}$ permeance as well as selectivity of $\mathrm{CO}_{2} / \mathrm{CH}_{4}$ due to reduced contribution by the facilitated transport mechanism. The possible strategies to overcome membrane plasticization are crosslinking of membrane material [82] and fabrication of mechanical strength enhanced membranes, such as the mixed matrix membrane by adding inorganic fillers to the polymer matrix. Adams et al. prepared a 50\% (vol.) Zeolite 4A/poly (vinyl acetate) (PVAc) MMM for $\mathrm{CO}_{2}$ separation from natural gas [83]. They found that the prepared MMMs can approach the Robeson $\mathrm{CO}_{2} / \mathrm{CH}_{4}$ upper bound, and at low $\mathrm{CO}_{2}$ partial pressures, $\mathrm{CO}_{2}$ permeability roughly doubled with a nearly $50 \%$ increase in selectivity versus pure PVAc under the same conditions. While at high $\mathrm{CO}_{2}$ partial pressure, $\mathrm{CO}_{2}$ permeability remained effectively unchanged with a $63 \%$ increase in selectivity comparing to pure PVAc. Their membranes showed promise for application in high pressure natural gas sweetening. He et al. reported that carbon nanotubes (CNTs) reinforced with the PVAm/PVA blend FSC membrane presented a good $\mathrm{CO}_{2} \mathrm{CH}_{4}$ 
separation performance with a $\mathrm{CO}_{2}$ permeance of $0.11 \mathrm{~m}^{3}(\mathrm{STP}) /\left(\mathrm{m}^{2} \mathrm{~h}\right.$ bar $)$ and a $\mathrm{CO}_{2} / \mathrm{CH}_{4}$ selectivity of 22 at 30 bar [84]. It shows a more secure mechanical strength to maintain a good separation performance even at high pressure.

Process design for $\mathrm{CO}_{2}$ removal by membrane system from natural gas depends on the membrane permeance and selectivity, $\mathrm{CO}_{2}$ concentration in feed stream, specific separation requirement, as well as the location of the plant. Peters et al. conducted process design, simulation, and optimization for $\mathrm{CO}_{2}$ removal from natural gas using HYSYS integrated with an in-house membrane programme [17]. They reported that a two-stage membrane system with a $\mathrm{CO}_{2}$ permeance $0.3 \mathrm{~m}^{3}(\mathrm{STP}) /\left(\mathrm{m}^{2} \mathrm{~h}\right.$ bar $)$ and a $\mathrm{CO}_{2} / \mathrm{CH}_{4}$ selectivity 40 is comparable to that of an amine process. Although the $\mathrm{CH}_{4}$ purity (98\%) of the sweet gas is lower compared to amine method (99.5\%), it can achieve $\mathrm{n}$ gas sales standard $\left(<2 \% \mathrm{CO}_{2}\right.$ in natural gas). However, $\mathrm{CO}_{2}$ purity $(90 \%)$ in the permeate stream needs to be further improved for pipeline transportation and storage since $10 \%$ non- $\mathrm{CO}_{2}$ gas is needlessly compressed and will cost extra energy - this can be achieved by process design and optimization. A combination of hybrid process comprising a membrane system for bulk removal of $\mathrm{CO}_{2}$ from crude natural gas feed with an amine unit for final purification to reach the pipeline specification $\left(<2 \% \mathrm{CO}_{2}\right)$ was designed by Bhide et al. [85]. Baker et al. also pointed out that a combination of a membrane system with an amine unit could offer a low-cost alternative to all-amine or all-membrane plants [16]. The future direction of natural gas sweetening using membrane systems will be the development of high performance membranes with an active layer on the order of $0.1 \mu \mathrm{m}$ in order to compete with other separation methods. In addition, membranes should also have to be: resistant to warm and high pressure operating conditions and mechanically strong. Membrane plasticization and long-term compaction at high pressure should be further investigated. Moreover, how to predict the long-term performance in commercial application based on the short-term lab-scale tests could be a continuing challenge of a membrane system for high pressure natural gas sweetening. A few studies have been conducted on this issue where the researchers are studying the long-term performance of a polymeric PVAm/PVA membrane when exposed to $\mathrm{H}_{2} \mathrm{~S}$, MEG, TEG and higher hydrocarbons (HHC) which are usually present in natural gas. Their membranes seemed to tolerate the impurities relatively well, but were vulnerable to HHC [86,87].

\section{Biogas Upgrading}

Biogas is considered to be one of the most efficient means of utilizing renewable energy and reducing greenhouse gas emissions. The composition of biogas varies depending on the origin of the anaerobic digestion process, and the main components are methane $\left(\mathrm{CH}_{4}\right)$ and carbon dioxide $\left(\mathrm{CO}_{2}\right)$ as shown in Table 2 [88].

Table 2. Typical biogas composition from different sources [88].

\begin{tabular}{ccccccc}
\hline \multirow{2}{*}{ Process } & \multicolumn{9}{c}{ Composition (vol \%) } & & $\mathbf{H}_{\mathbf{2}} \mathbf{S} / \mathbf{S O}_{\mathbf{2}}$ \\
& $\mathbf{C O}_{\mathbf{2}}$ & $\mathbf{C H}_{\mathbf{4}}$ & $\mathbf{N}_{\mathbf{2}}$ & $\mathbf{O}_{\mathbf{2}}$ & $\mathbf{H}_{\mathbf{2}} \mathbf{O}$ & $\mathbf{( p p m )}$ \\
\hline Farm biogas plant & $37-38$ & $55-58$ & $<2$ & $<1$ & $4-7$ & $32-169$ \\
Sewage digester & 38.6 & 57.8 & 3.7 & 0 & $4-7$ & 62.9 \\
Landfill & $37-41$ & $47-57$ & $<1$ & $<1$ & $4-7$ & $36-115$ \\
\hline
\end{tabular}

* Siloxane is not included. 
Biogas can be used as a renewable energy source for heating, vehicle fuel, combined heat and power (CHP) generation, fuel cell and substitute natural gas. However, depending on the different end uses, specific biogas treatment should be executed. For applications such as vehicle fuel and natural gas grid injection, the acid gases of $\mathrm{CO}_{2}$ and $\mathrm{H}_{2} \mathrm{~S}$ should be removed from raw biogas, i.e., biogas upgrading. High content of $\mathrm{CO}_{2}$ in biogas will cause the risks of corrosion of pipeline and decrease the Wobbe index which is directly proportional to the methane concentration. Therefore, $\mathrm{CO}_{2}$ removal from natural gas is mandatory in all natural gas processing plants. However, biogas upgrading processes will add extra costs to biogas production, so it is important to find an optimized upgrading technology in terms of lower energy consumption and higher efficiency. Moreover, methane losses during upgrading should be minimized since methane has a greenhouse effect around 24 times higher than that of $\mathrm{CO}_{2}$.

Different techniques such as pressure swing adsorption (PSA), physical absorption (e.g., water scrubbing) [89], chemical absorption (e.g., amines) [90,91] and membrane separation [18,19] can be used for biogas upgrading. The choice of a suitable technology is mainly dependent on the specific conditions at a plant, such as availability of low price for heating, electricity and water, as well as the amount of gas to be handled. Today, most biogas upgrading plants in Sweden are using PSA. The upgraded gas has a typical methane concentration around $96 \%$ while methane loss is quite high $(3 \%-10 \%)$. Plants using water scrubbing will produce a lot of waste water, and electricity consumption is also quite high. Membrane systems could be favorable for biogas upgrading due to a series of advantages, including safety and simplicity of operation, and easy maintenance and operation without hazardous chemicals [18]. Compression of upgraded biogas may vary depending on whether it goes to natural gas grid or will be used for vehicle fuel. Biomethane for vehicle fuel must be compressed up to around 200 bar, while the pressure can be lower if injected into a natural gas pipeline network ( $<80$ bar). The main challenge for a membrane system is pre-treatment of biogas to remove $\mathrm{H}_{2} \mathrm{~S}$ and water vapor to protect the membranes, especially for sewage treatment plants and landfill sites where the produced biogases contain high number of malicious gas components such as siloxanes (siloxanes will be a serious problem for some polymeric membranes, e.g., PVDF). Deng et al. reported to use composite FSC membranes for biogas upgrading [19]. Their results indicated that membrane process with a $\mathrm{CH}_{4}$ recovery of $99 \%$ at a low operation cost could be designed to achieve natural gas grid specification, which made this environmentally friendly technique more competitive compared to the other conventional technologies currently used. Makaruk et al. pointed out that a membrane system provides enough flexibility for heat integration within biogas plants [18]. The expected energy requirement for a single produced cubic meter of natural gas substitute is around $0.3 \mathrm{kWh}$, which is close to the values that were reported in an industrial scale technology demonstration for membrane biogas upgrading plant at Bruck/Leitha in Austria [92]. Moreover, a new carbon membrane company MemfoACT (www.memfoact.no) was launched in 2008 in Norway, which mainly focuses on biogas upgrading using carbon membranes. Their contributions could be promising to bring this technique into commercial application in the near future. 


\section{Hydrogen Production/Recovery}

Hydrogen energy composes the promise of zero emissions as well as energy independence and safety in the transportation sector, which can be produced and recovered from different processes using membrane systems, as summarized in Table 3. Hydrogen can be generated from a readily available source: water electrolysis based on a proton-exchange membrane (PEM). PROTON developed a PEM electrolyzer FuelGen ${ }^{\circledR}$ to produce high purity hydrogen fuels [20]. Norsk Hydro built a wind/hydrogen energy demonstration system using a PEM electrolyzer and fuel cells at the island of Utsira in Norway 2004, as shown in Figure 3 [21] — this is, however, no longer operational. This system provided two to three days of full energy autonomy for 10 households on the island, and was the first of its kind in the world as reported by Ulleberg et al. [93].

Table 3. Main applications of membrane system for $\mathrm{H}_{2}$ production and recovery.

\begin{tabular}{llll}
\hline Separation & Process & Membrane & Status \\
\hline $\begin{array}{l}\mathrm{H}_{2} \text { production by water } \\
\text { electrolysis }\end{array}$ & $\mathrm{H}_{2}$ PEM electrolyzer & PEM, FuelGen ${ }^{\circledR}$ & $\begin{array}{l}\text { Commercial } \\
\text { production }\end{array}$ \\
\hline Wind/ $\mathrm{H}_{2}$ power system & PEM electrolyzer and fuel cells & PEM & $\begin{array}{l}\text { Pilot-scale } \\
\text { demonstration }\end{array}$ \\
\hline $\mathrm{H}_{2} / \mathrm{CO}$ & $\begin{array}{l}\text { Methanol steam reforming } \\
\text { membrane reactors }\end{array}$ & $\begin{array}{l}\text { Pd and CMS } \\
\text { membrane }\end{array}$ & Lab-scale \\
\hline $\mathrm{H}_{2} / \mathrm{CO}$ & $\begin{array}{l}\text { Adjustment of } \mathrm{H}_{2} / \mathrm{CO} \text { ratio in } \\
\text { syngas }\end{array}$ & $\begin{array}{l}\text { Silicon rubber, } \\
\text { polyimide }\end{array}$ & Plant installed \\
\hline $\mathrm{H}_{2} / \mathrm{N}_{2}$ & Ammonia purge gas & Prism ${ }^{\circledR}$ & Plant installed \\
\hline $\mathrm{H}_{2} / \mathrm{Hydrocarbon}$ & Hecovery in refineries & $\begin{array}{l}\text { Silicon rubber, } \\
\text { polyimide }\end{array}$ & Plant installed \\
\hline $\mathrm{H}_{2} / \mathrm{CH}_{4}$ & $\begin{array}{l}\text { Natural gas network } \\
\text { transportation }\end{array}$ & $\begin{array}{l}\text { Carbon molecular } \\
\text { sieve membranes }\end{array}$ & Lab-scale \\
\hline
\end{tabular}

Figure 3. Utsira wind/hydrogen demonstration plant based on proton-exchange membrane (PEM) electrolyzer [21].

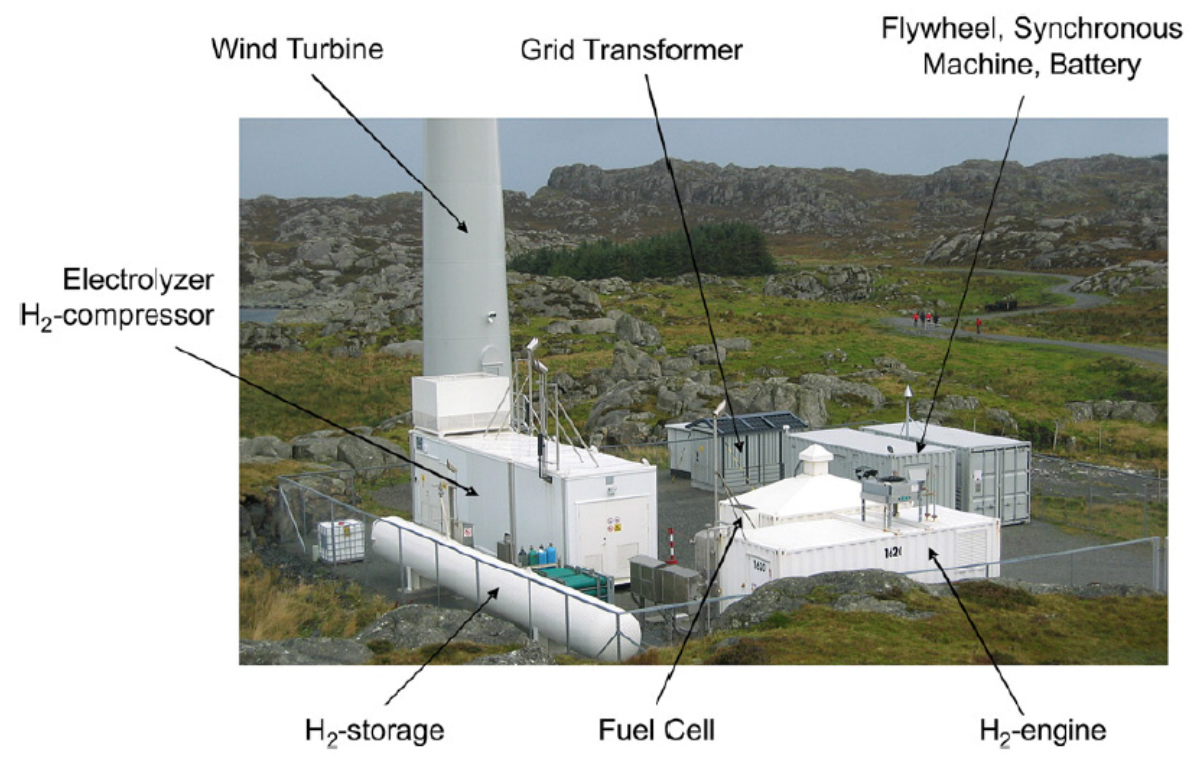


Hydrogen can also be produced from some industrial processes using membrane systems. The first commercial application of a membrane system for gas separation is hydrogen recovery from the ammonia purge gas using Prism ${ }^{\circledR}$ system produced by Air Products [94]. Hydrogen has a very high permeance compared to other gases such as nitrogen and argon, and the high purge pressure (136 bar) in the ammonia process provides enough driving force for gas permeation. This system can achieve a 95\% hydrogen recovery, and the recovered hydrogen can reach a high purity of $98 \%$ either for the recycle to synthesis loop or in other processes. Industrial hydrogen recovery in refinery plants is mainly carried out by pressure swing adsorption (PSA) and cryogenic separation, while recent membrane systems attract great interest in this area due to their low capital cost and low energy demands. Brunette et al. conducted a review on the comparison between PSA, cryogenics and membrane systems for $\mathrm{H}_{2}$ recovery from refineries based on their process flexibility, reliability, ease of response to the variations, and expansion capability [95]. They concluded that choosing a suitable technique will mainly depend on feed composition, feed pressure, product flow rate as well as the requirements of product purity. The membrane system showed a lower energy intensity and smaller footprint compared to the other two processes. Recently, $\mathrm{H}_{2}$ production using two types of membranes (Palladium (Pd) and carbon molecular sieve (CMS) membranes) in a methanol steam reforming membrane reactor (MR) was reported by Sá et al. [22]. Their results indicated that CMS membranes presented higher permeability, higher hydrogen recovery, and lower selectivity, while Pd membranes were more expensive but exhibited much higher selectivity towards hydrogen. A combined CMS $+\mathrm{Pd}$ membrane reactor revealed some advantages compared to either CMS-MR or Pd-MR.

If a hydrogen energy-based society is realized, a hydrogen distribution system must be built for hydrogen transportation which will take a long time. A feasible solution is to use the existing natural gas pipeline networks to transport a $\mathrm{H}_{2}$ and natural gas mixture, which was proposed by NaturalHy project (6th EU framework) [96]. In that project, Grainger et al. studied the separation performance of $\mathrm{H}_{2} / \mathrm{CH}_{4}$ with carbon molecular sieve membranes based on experiments and process simulation [97]. Their techno-economic evaluation results indicated that carbon molecular sieve membranes can offer a great potential for hydrogen separation from hydrocarbon, and high purity hydrogen can be recovered from leaner streams in natural gas networks with a low energy consumption.

\section{Volatile Organic Compounds Recovery}

Volatile organic compounds (VOC) might be recovered, instead of being released to atmosphere since some of these compounds are involved in atmospheric pollutions and are strong greenhouse gases. Different techniques such as condensation, absorption, adsorption and vapor permeation, etc., can be used for VOC recovery [98]. Among them, vapor permeation membranes attract great interest for VOC recovery from gas streams in various industrial processes, such as polyolefin plant resin degassing and gasoline vapor recovery in large retail gasoline stations $[15,99,100]$. The main application of vapor separation membranes is the recovery of hydrocarbon monomers from ethylene and polyethylene and polypropylene plants. Following the development of vapor/gas separation membranes, more and more polyolefin plants have installed hydrocarbon recovery units. A schematic process flow diagram of a typical membrane system integrated into a polyolefin plant is shown in Figure 4 [15]. The vapor-enriched permeate stream is recycled to the compressor's inlet, while high 
purity $\mathrm{N}_{2}$ is sent to the second stage membrane unit for further purification. Membrane Technology and Research, Inc. (MTR) developed a VaporSep ${ }^{\circledR}$ system for propylene recovery from polypropylene (PP) production plants, which has been installed in many petrochemical plants around the world during the last 10 years.

Figure 4. A schematic process flow diagram of a membrane propylene recovery system [15].

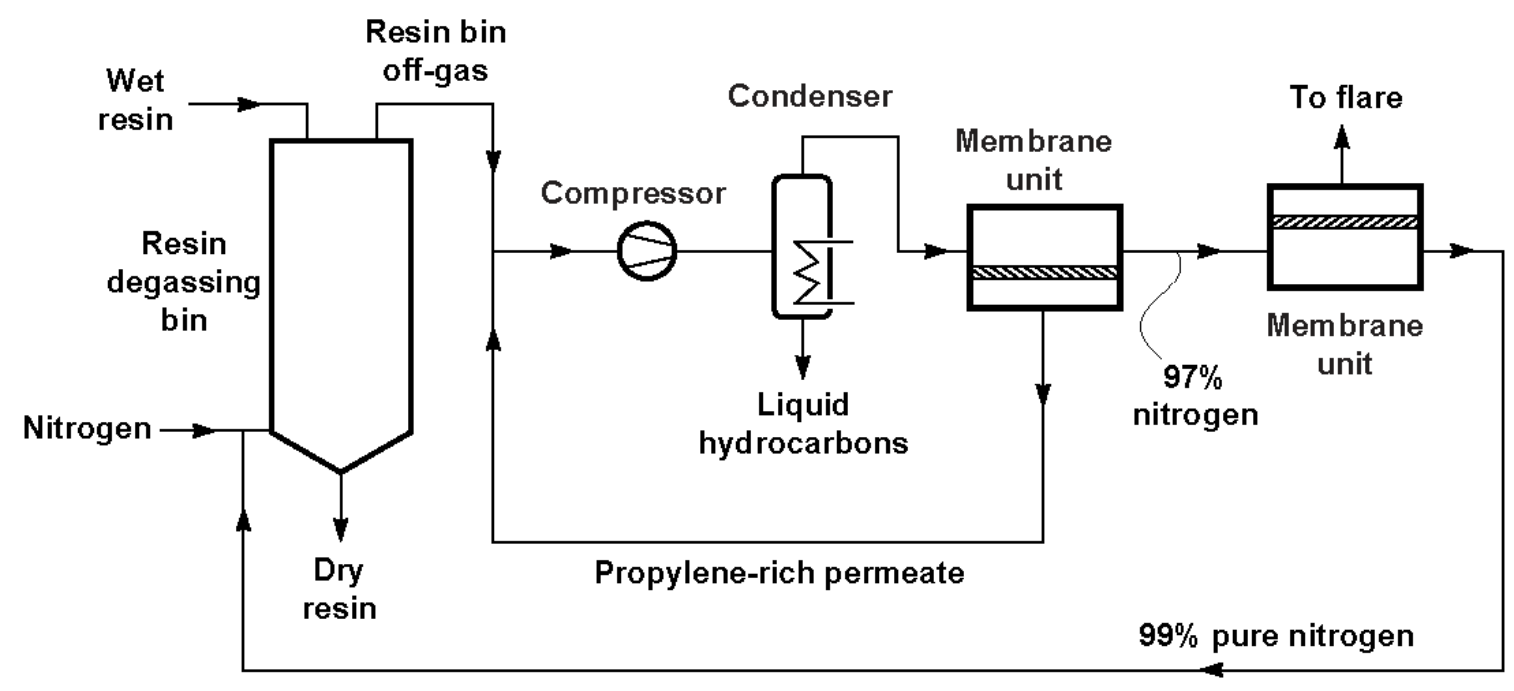

Gasoline vapor recovery is becoming another important business for membrane gas separation systems. Many gasoline retail stations have installed membrane systems to recover hydrocarbon vapor when it was transferred from trucks to tanks. Some representative companies such as GKSS [101] and MTR [102] have developed gasoline vapor recovery systems for reduction of hydrocarbon emissions. The OPW Vaporsaver ${ }^{\mathrm{TM}}$ system [103], fitted with MTR's membranes, is used for recovery of gasoline vapors and can reduce hydrocarbon emissions by $95 \%-99 \%$.

\section{Pressure Retarded Osmosis}

Pressure retarded osmosis (PRO) has the potential to produce renewable energy from natural and anthropogenic salinity gradients [7]. In a PRO system, water from a low salinity solution permeates through a membrane into a pressurized, high salinity solution; power is generated by depressurizing the permeate through a hydroturbine, as shown in Figure 5 [35]. The concept of energy production from the mixing of fresh water and salt water was first proposed by Pattle [104]. The continuous availability of both natural water resources (sea water) and anthropogenic waste streams showed a great potential of PRO technology for renewable energy production. However, development of PRO technology has been hindered due to the lack of a suitable membrane. Traditional reverse osmosis (RO) membranes cause a severe internal concentration polarization (ICP) phenomenon, which could decrease the water flux significantly. Thus, RO membranes can only achieve a low power density (power produced per membrane area) in a PRO operation unit. Another type of membrane: forward osmosis (FO), suffers less ICP influence, but the relatively low water flux also restricts a PRO system from attaining a high power density $[35,36]$. Statkraft built the world's first prototype osmosis power plant in Norway to demonstrate PRO technology (power density $<0.5 \mathrm{~W} / \mathrm{m}^{2}$ ) [105], and today's membranes can produce close to $3 \mathrm{~W} / \mathrm{m}^{2}$. Although power density is still lower than the requirement 
for commercial viability (power density of 4-6 W/m $\mathrm{m}^{2}$ [106]), development of higher performance FO membranes could promote PRO technology to be commercialized for renewable energy production in the near future.

Figure 5. A schematic diagram for pressure retarded osmosis (PRO) power generation system [35].

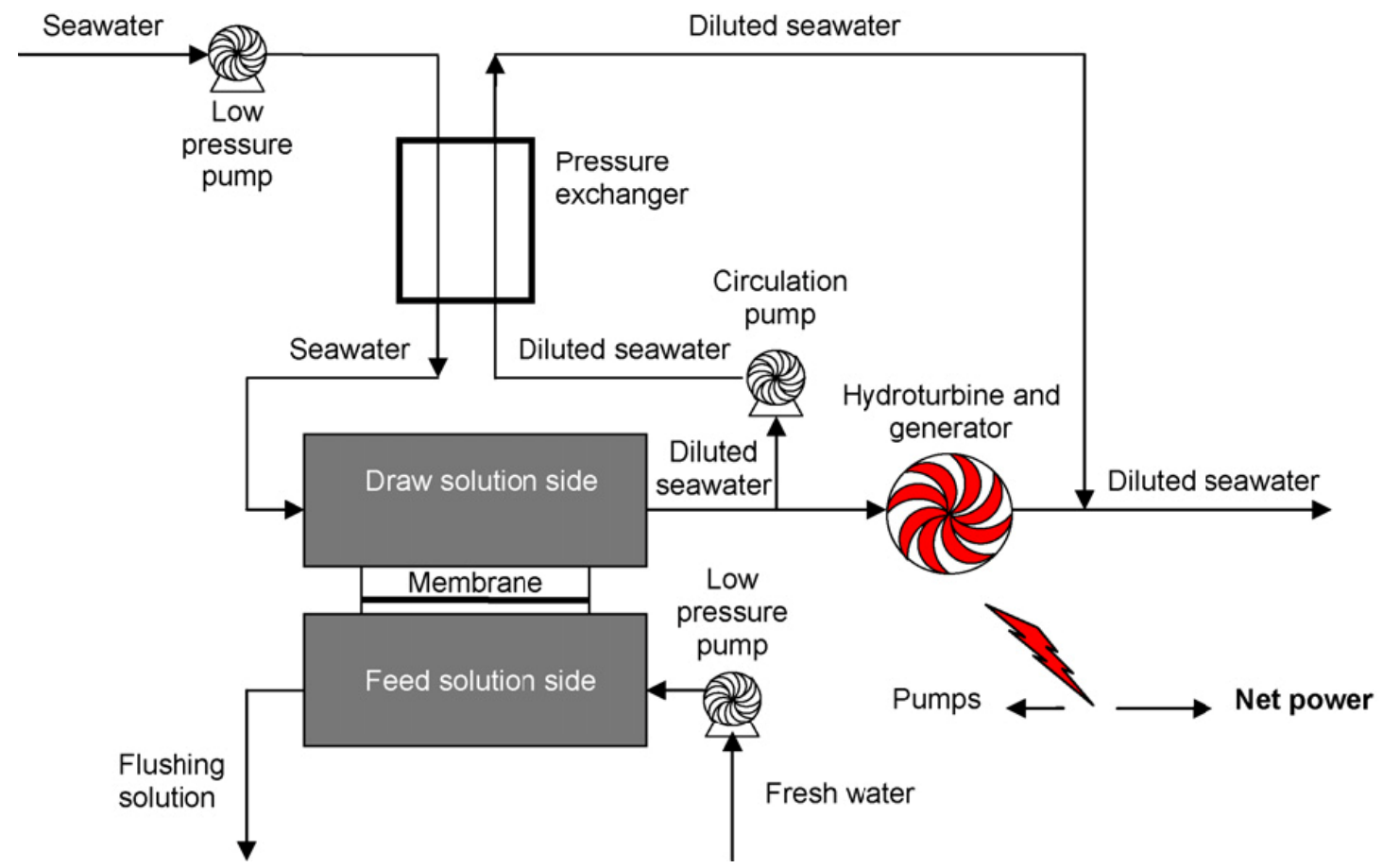

\section{Future Directions}

Membrane technology shows strong potentials in various energy processes including $\mathrm{CO}_{2}$ capture from flue gas in power plants, natural gas sweetening, biogas upgrading, $\mathrm{H}_{2}$ recovery, VOC recovery as well as power PRO generation. However, for any kind of suitable application, a high performance membrane material is required, while taking into consideration some key parameters such as transport properties, durability and mechanical strength. The following aspects can be further investigated to achieve a high efficiency membrane process:

- Membrane transport properties (pemeance and selectivity)

- Mechanical strength, chemical and thermal stability under a specific operating condition

- Membrane durability over the long term by being exposed to real process conditions

- Membrane module design

- Process design, simulation, optimization and integration

Three specific parameters - environmental, economic and social indicators - are usually employed to compare membrane systems with the other traditional unit operations towards sustainability, and evaluate which technique could be more suitable for a specific application. However, for any specific application, process conditions need to be carefully considered before making a decision. Nevertheless, the prediction is that membrane systems, which require no or very little chemicals compared to standard unit operations, in addition to being easy to scale up and having low energy consumption, will be an environmentally friendly technology for application in energy processes in the future. 


\section{Acknowledgements}

The authors want to acknowledge the various project partners in our energy related projects; the Research Council of Norway, Statoil and Petrobras for funding of this study.

\section{References}

1. International Energy Outlook 2011. Available online: http://www.eia.gov/ieo/pdf/0484(2011).pdf (accessed on 16 October 2012).

2. Michael, K.; Golab, A.; Shulakova, V.; Ennis-Kinga, J.; Allinson, G.; Sharma, S.; Aiken, T. Geological storage of $\mathrm{CO}_{2}$ in saline aquifers - A review of the experience from existing storage operations. Int. J. Greenh. Gas Control 2010, 4, 659-667.

3. New Way to Convert $\mathrm{CO}_{2}$ into Methanol. Available online: http://www.alternative-energynews.info/new-way-to-convert-co2-into-methanol/ (accessed on 16 October 2012).

4. Exxon Makes Big Investment in Algae Biofuels. Available online: http://www.heatusa.com/ energy-conservation/exxon-big-investment-algae-biofuels/ (accessed on 16 October 2012).

5. Evans, A.; Strezov, V.; Evans, T.J. Assessment of sustainability indicators for renewable energy technologies. Renew. Sustain. Energy Rev. 2009, 13, 1082-1088.

6. Loeb, S. Production of energy from concentrated brines by pressure-retarded osmosis: I. Preliminary technical and economic correlations. J. Membr. Sci. 1976, 1, 49-63.

7. Achilli, A.; Childress, A.E. Pressure retarded osmosis: From the vision of Sidney Loeb to the first prototype installatio-Review. Desalination 2010, 261, 205-211.

8. Ockwig, N.W.; Nenoff, T.M. Membranes for Hydrogen Separation. Chem. Rev. 2007, 107, 4078-4110.

9. Bredesen, R.; Jordal, K.; Bolland, O. High-temperature membranes in power generation with $\mathrm{CO}_{2}$ capture. Chem. Eng. Process. 2004, 43, 1129-1158.

10. Brunetti, A.; Scuraa, F.; Barbieria, G.; Drioli, E. Membrane technologies for $\mathrm{CO}_{2}$ separation. $J$. Membr. Sci. 2010, 359, 115-125.

11. Hagg, M.B.; Lindbrathen, A. $\mathrm{CO}_{2}$ Capture from Natural Gas Fired Power Plants by Using Membrane Technology. Ind. Eng. Chem. Res. 2005, 44, 7668-7675.

12. Huang, J.; Zou, J.; Ho, W.S.W. Carbon Dioxide Capture Using a $\mathrm{CO}_{2}$-Selective Facilitated Transport Membrane. Ind. Eng. Chem. Res. 2008, 47, 1261-1267.

13. Hussain, A.; Hägg, M.-B. A feasibility study of $\mathrm{CO}_{2}$ capture from flue gas by a facilitated transport membrane. J. Membr. Sci. 2010, 359, 140-148.

14. Yang, H.; Xua, Z.; Fanb, M.; Guptaa, R.; Slimanec, R.B.; Blandd, A.E.; Wrighte, I. Progress in carbon dioxide separation and capture: A review. J. Environ. Sci. 2008, 20, 14-27.

15. Baker, R.W. Membranes for Vapor/Gas Separation. Available online: http://www.mtrinc.com/ publications/MT01\%20Fane\%20Memb\%20for\%20VaporGas_Sep\%202006\%20Book\%20Ch.pdf (accessed on 16 October 2012).

16. Baker, R.W.; Lokhandwala, K. Natural Gas Processing with Membranes: An Overview. Ind. Eng. Chem. Res. 2008, 47, 2109-2121. 
17. Peters, L.; Hussain, A.; Follmann, M.; Melin, T.; Hägg, M.B. $\mathrm{CO}_{2}$ removal from natural gas by employing amine absorption and membrane technology-A technical and economical analysis. Chem. Eng. J. 2011, 172, 952-960.

18. Makaruk, A.; Miltner, M.; Harasek, M. Membrane biogas upgrading processes for the production of natural gas substitute. Sep. Purif. Technol. 2010, 74, 83-92.

19. Deng, L.; Hägg, M.-B. Techno-economic evaluation of biogas upgrading process using $\mathrm{CO}_{2}$ facilitated transport membrane. Int. J. Greenh. Gas Control 2010, 4, 638-646.

20. Hydrogen Fueling Systems. Available online: http://www.protononsite.com/technology/ hydrogen-fueling-systems.html (accessed on 16 October 2012).

21. Utsira Wind Power and Hydrogen Plant. Available online: http://www.iphe.net/docs/ Renew_H2_Ustira.pdf (accessed on 16 October 2012).

22. Sá, S.; Silvaa, H.; Sousaa, J.M.; Mendes, A. Hydrogen production by methanol steam reforming in a membrane reactor: Palladium vs. carbon molecular sieve membranes. J. Membr. Sci. 2009, 339, 160-170.

23. Carapellucci, R.; Milazzo, A. Membrane systems for $\mathrm{CO}_{2}$ capture and their integration with gas turbine plants. Proc. Inst. Mech. Eng. A J. Power Energy 2003, 217, 505-517.

24. Reijerkerk, S.R. Polyether Based Block Copolymer Membranes for $\mathrm{CO}_{2}$ Separation. Ph.D. Thesis, University of Twente, Enschede, the Netherlands, 2010.

25. Lin, H.; Freeman, B.D. Materials selection guidelines for membranes that remove $\mathrm{CO}_{2}$ from gas mixtures. J. Mol. Struct. 2005, 739, 57-74.

26. Deng, L.; Kim, T.-J.; Hägg, M.-B. Facilitated transport of $\mathrm{CO}_{2}$ in novel PVAm/PVA blend membrane. J. Membr. Sci. 2009, 340, 154-163.

27. Sandru, M.; Haukebø, S.H.; Hägg, M.-B. Composite hollow fiber membranes for $\mathrm{CO}_{2}$ capture. J. Membr. Sci. 2010, 346, 172-186.

28. He, X.; Hägg, M.-B. Hollow fiber carbon membranes: Investigations for $\mathrm{CO}_{2}$ capture. J. Membr. Sci. 2011, 378, 1-9.

29. Bernardo, P.; Drioli, E. Membrane gas separation progresses for process intensification strategy in the petrochemical industry. Pet. Chem. 2010, 50, 271-282.

30. Bernardo, P.; Drioli, E.; Golemme, G. Membrane gas separation: A review/state of the art. Ind. Eng. Chem. Res. 2009, 48, 4638-4663.

31. Robeson, L.M. The upper bound revisited. J. Membr. Sci. 2008, 320, 390-400.

32. Rasten, E.; Hagen, G.; Tunold, R. Electrocatalysis in water electrolysis with solid polymer electrolyte. Electrochim. Acta 2003, 48, 3945-3952.

33. Grigoriev, S.A.; Porembsky, V.I.; Fateev, V.N. Pure hydrogen production by PEM electrolysis for hydrogen energy. Int. J. Hydrog. Energy 2006, 31, 171-175.

34. Tanaka, Y.; Uchinashia, S.; Saiharaa, Y.; Kikuchic, K.; Okayac, T.; Ogumib, Z. Dissolution of hydrogen and the ratio of the dissolved hydrogen content to the produced hydrogen in electrolyzed water using SPE water electrolyzer. Electrochim. Acta 2003, 48, 4013-4019.

35. Achilli, A.; Cath, T.Y.; Childress, A.E. Power generation with pressure retarded osmosis: An experimental and theoretical investigation. J. Membr. Sci. 2009, 343, 42-52. 
36. Xu, Y.; Penga, X.; Tang, C.Y.; Fu, Q.S.; Nie, S. Effect of draw solution concentration and operating conditions on forward osmosis and pressure retarded osmosis performance in a spiral wound module. J. Membr. Sci. 2010, 348, 298-309.

37. Kim, J.; Lee, J.; Kim, J.H. Overview of pressure-retarded osmosis (PRO) process and hybrid application to sea water reverse osmosis process. Desalin. Water Treat. 2012, 43, 193-200.

38. Skilhagen, S.E.; Dugstad, J.E.; Aaberg, R.J. Osmotic power-power production based on the osmotic pressure difference between waters with varying salt gradients. Desalination 2008, 220, 476-482.

39. $\mathrm{CO}_{2}$ Capture and Storage-VGB Report on the State of the Art. Available online: http://www.vgb.org/vgbmultimedia/Fachgremien/Umweltschutz/VGB+Capture+and+Storage.pdf (accessed on 16 October 2012).

40. Favre, E. Membrane processes and postcombustion carbon dioxide capture: Challenges and prospects. Chem. Eng. J. 2011, 171, 782-793.

41. Hägg, M.B.; Sandru, M.; Kim, T.J.; Capala, W.; Huijbers, M. Report on pilot scale testing and further development of a facilitated transport membrane for $\mathrm{CO}_{2}$ capture from power plants. Presented at Euromembrane 2012, London, UK, September 2012.

42. He, X. Development of Hollow Fiber Carbon Membranes for $\mathrm{CO}_{2}$ Separation. Ph.D. Thesis, Norwegian University of Science and Technology: Trondheim, Norway, 2011.

43. He, X.; Lie, J.A.; Sheridan, E.; Hägg, M.-B. Preparation and characterization of hollow fiber carbon membranes from cellulose acetate precursors. Ind. Eng. Chem. Res. 2011, 50, 2080-2087.

44. He, X.; Lie, J.A.; Sheridan, E.; Hägg, M.-B. $\mathrm{CO}_{2}$ capture by hollow fibre carbon membranes: Experiments and process simulations. Energy Procedia 2009, 1, 261-268.

45. Rao, A.B.; Rubin, E.S. A Technical, Economic, and Environmental Assessment of Amine-Based $\mathrm{CO}_{2}$ Capture Technology for Power Plant Greenhouse Gas Control. Environ. Sci. Technol. 2002, 36, 4467-4475.

46. Merkel, T.C.; Lin, H.; Wei, X.; Baker, R. Power plant post-combustion carbon dioxide capture: An opportunity for membranes. J. Membr. Sci. 2010, 359, 126-139.

47. Integrating Mea Regeneration with $\mathrm{CO}_{2}$ Compression and Peaking to Reduce $\mathrm{CO}_{2}$ Capture Costs. Available online: http://trimeric.com/Report\%20060905.pdf (accessed on 16 October 2012).

48. Grainger, D. Development of Carbon Membranes for Hydrogen Recovery. Ph.D. Thesis, Norwegian University of Science and technology, Trondheim, Norway, 2007.

49. Zhao, W.; He, G.; Nie, F.; Zhang, L.; Feng, H.; Liu, H. Membrane liquid loss mechanism of supported ionic liquid membrane for gas separation. J. Membr. Sci. 2012, 411-412, 73-80.

50. Cserjési, P.; Nemestóthy, N.; Bélafi-Bakó, K. Gas separation properties of supported liquid membranes prepared with unconventional ionic liquids. J. Membr. Sci. 2010, 349, 6-11.

51. Uchytil, P.; Schauer, J.; Petrychkovych, R.; Setnickova, K.; Suen, S.Y. Ionic liquid membranes for carbon dioxide-methane separation. J. Membr. Sci. 2011, 383, 262-271.

52. Neves, L.A.; Crespo, J.G.; Coelhoso, I.M. Gas permeation studies in supported ionic liquid membranes. J. Membr. Sci. 2010, 357, 160-170.

53. Kim, D.-H.; Baek, I.-H.; Hong, S.-U.; Lee, H.-K. Study on immobilized liquid membrane using ionic liquid and PVDF hollow fiber as a support for $\mathrm{CO}_{2} / \mathrm{N}_{2}$ separation. J. Membr. Sci. 2011, 372, $346-354$. 
54. Krull, F.F.; Fritzmann, C.; Melin, T. Liquid membranes for gas/vapor separations. J. Membr. Sci. 2008, 325, 509-519.

55. Dindore, V.Y.; Brilman, D.W.F.; Feron, P.H.M.; Versteeg, G.F. $\mathrm{CO}_{2}$ absorption at elevated pressures using a hollow fiber membrane contactor. J. Membr. Sci. 2004, 235, 99-109.

56. Bottino, A.; Capannelli, G.; Comite, A.; Di Felice, R.; Firpo, R. $\mathrm{CO}_{2}$ removal from a gas stream by membrane contactor. Sep. Purif. Technol. 2008, 59, 85-90.

57. Chabanon, E.; Roizard, D.; Favre, E. Membrane contactors for postcombustion carbon dioxide capture: A comparative study of wetting resistance on long time scales. Ind. Eng. Chem. Res. 2011, 50, 8237-8244.

58. de Montigny, D.; Tontiwachwuthikul, P.; Chakma, A. Using polypropylene and polytetrafluoroethylene membranes in a membrane contactor for $\mathrm{CO}_{2}$ absorption. J. Membr. Sci. 2006, 277, 99-107.

59. Feron, P.H.M.; Jansen, A.E. $\mathrm{CO}_{2}$ separation with polyolefin membrane contactors and dedicated absorption liquids: performances and prospects. Sep. Purif. Technol. 2002, 27, 231-242.

60. Yeon, S.-H.; Lee, K.-S.; Sea, B.; Park, Y.-I.; Lee, K.-H. Application of pilot-scale membrane contactor hybrid system for removal of carbon dioxide from flue gas. J. Membr. Sci. 2005, 257, 156-160.

61. Li, J.-L.; Chen, B.-H. Review of $\mathrm{CO}_{2}$ absorption using chemical solvents in hollow fiber membrane contactors. Sep. Purif. Technol. 2005, 41, 109-122.

62. Mansourizadeh, A.; Ismail, A.F. Hollow fiber gas-liquid membrane contactors for acid gas capture: A review. J. Hazard. Mater. 2009, 171, 38-53.

63. Scholes, C.A.; Smith, K.H.; Kentish, S.E.; Stevens, G.W. $\mathrm{CO}_{2}$ capture from pre-combustion processes-Strategies for membrane gas separation. Int. J. Greenh. Gas Control 2010, 4, 739-755.

64. Gao, H.; Lin, Y.S.; Li, Y.; Zhang, B. Chemical Stability and Its Improvement of PalladiumBased Metallic Membranes. Ind. Eng. Chem. Res. 2004, 43, 6920-6930.

65. Peters, T.A.; Kaleta, T.; Stange, M.; Bredesen, R. Development of thin binary and ternary Pd-based alloy membranes for use in hydrogen production. J. Membr. Sci. 2011, 383, 124-134.

66. Yun, S.; Oyama, S.T. Correlations in palladium membranes for hydrogen separation: A review. J. Membr. Sci. 2011, 375, 28-45.

67. Krishnan, G.; Steele, D.; O’Brien, K.; Callahan, R.; Berchtold, K.; Figueroa, J. Simulation of a process to capture $\mathrm{CO}_{2}$ from IGCC syngas using a high temperature PBI membrane. Energy Procedia 2009, 1, 4079-4088.

68. Grainger, D.; Hägg, M.-B. Techno-economic evaluation of a $\mathrm{PVAm} \mathrm{CO}_{2}$-selective membrane in an IGCC power plant with $\mathrm{CO}_{2}$ capture. Fuel 2008, 87, 14-24.

69. Habib, M.A.; Badr, H.M.; Ahmed, S.F.; Ben-Mansour, R.; Mezghani, K.; Imashuku, S.; la O', G.J.; Shao-Horn, Y.; Mancini, N.D.; Mitsos, A.; Kirchen, P.; Ghoneim, A.F. A review of recent developments in carbon capture utilizing oxy-fuel combustion in conventional and ion transport membrane systems. Int. J. Energy Res. 2011, 35, 741-764.

70. Tan, X.; Pang, Z.; Li, K. Oxygen production using $\mathrm{La}_{0.6} \mathrm{Sr}_{0.4} \mathrm{Co}_{0.2} \mathrm{Fe}_{0.8} \mathrm{O}_{3-\alpha}$ (LSCF) perovskite hollow fibre membrane modules. J. Membr. Sci. 2008, 310, 550-556. 
71. Liu, S.; Gavalas, G.R. Oxygen selective ceramic hollow fiber membranes. J. Membr. Sci. 2005, 246, 103-108.

72. Armstrong, P.A.; Foster, E.P.; Gunardson, H.H. ITM oxygen for gasification. In SPE/PS-CIM/CHOA International Thermal Operations and Heavy Oil Symposium; Society of Petroleum Engineers: Calgary, Alberta, Canada, 2005.

73. Clements, B.R.; Zheng, L.; Pomalis, R. Next generation oxy-fired systems: Potential for energy efficiency improvement through pressurization. In ASME 2009 3rd International Conference of Energy Sustainability, San Francisco, California, USA, 19-23 July 2009.

74. Gazzino, M.; Benelli, G. Pressurized oxy-coal combustion Rankine-cycle for future zero emission power plants: Process design and energy analysis. In The 2nd International Conference on Energy Sustainability, Jacksonville, FL, USA, 10-14 August 2008.

75. Fassbender, A. Simplification of carbon capture power plants using pressurized oxyfuel. In The 32nd International Technical Conference on Coal Utilization and Fuel Systems, Clearwater, FL, USA, 2007.

76. Fassbender, A.; Tao, L.; Henry, R. Physical properties and liquid vapor equilibrium of pressurized $\mathrm{CO} 2$ rich gases from pressurized oxy-fuel combustion of coal. In The 33rd International Technical Conference on Coal Utilization and Fuel Systems, Clearwater, FL, USA, 2008.

77. Pomalis, R.; Zheng, L.; Clements, B. ThermoEnergy integrated power system economics. In The 32nd International Technical Conference on Coal Utilization and Fuel Systems, Clearwater, FL, USA, 2007.

78. Callison, A.; Davidson, G. Offshore processing plant uses membranes for $\mathrm{CO}_{2}$ removal. Oil Gas J. 2007, 105, 56-65.

79. Deng, L.; Kim, T.-J.; Sandru, M.; Hägg, M.-B. PVA/PVAm blend FSC membrane for natural gas sweetening. In Proceedings of the 1st Annual Gas Processing Symposium, Doha, Qatar, 2009.

80. Donohue, M.D.; Minhas, B.S.; Lee, S.Y. Permeation behavior of carbon dioxide-methane mixtures in cellulose acetate membranes. J. Membr. Sci. 1989, 42, 197-214.

81. Wind, J.D.; Paul, D.R.; Koros, W.J. Natural gas permeation in polyimide membranes. J. Membr. Sci. 2004, 228, 227-236.

82. Wind, J.D.; Staudt-Bickel, C.; Paul, D.R.; Koros, W.J. The effects of crosslinking chemistry on $\mathrm{CO}_{2}$ plasticization of polyimide gas separation membranes. Ind. Eng. Chem. Res. 2002, 41, 6139-6148.

83. Adams, R.T.; Lee, J.S.; Bae, T.-H.; Ward, J.K.; Johnson, J.R. Jones, C.W.; Nair, S.; Koros, W.J. $\mathrm{CO}_{2}-\mathrm{CH}_{4}$ permeation in high zeolite 4A loading mixed matrix membranes. J. Membr. Sci. 2011, 367, 197-203.

84. He, X.; Hägg, M.B. Hybrid fixed-site-carrier membranes for $\mathrm{CO}_{2} / \mathrm{CH}_{4}$ separation. In Euromembrane 2012, London, UK, September 2012.

85. Bhide, B.D.; Voskericyan, A.; Stern, S.A. Hybrid processes for the removal of acid gases from natural gas. J. Membr. Sci. 1998, 140, 27-49.

86. Uddin, M.W.; Hägg, M.-B. Natural gas sweetening - the effect on $\mathrm{CO}_{2}-\mathrm{CH}_{4}$ separation after exposing a facilitated transport membrane to hydrogen sulfide and higher hydrocarbons. $J$. Membr. Sci. 2012, 423-424, 143-149. 
87. Uddin, M.W.; Hägg, M.-B. Effect of monoethylene glycol and triethylene glycol contamination on $\mathrm{CO}_{2} / \mathrm{CH}_{4}$ separation of a facilitated transport membrane for natural gas sweetening. J. Membr. Sci. 2012, 423-424, 150-158.

88. Rasi, S.; Veijanen, A.; Rintala, J. Trace compounds of biogas from different biogas production plants. Energy 2007, 32, 1375-1380.

89. Rasi, S.; Läntelä, J.; Veijanen, A.; Rintala, J. Landfill gas upgrading with countercurrent water wash. Waste Manag. 2008, 28, 1528-1534.

90. Gaur, A.; Park, J.-W.; Maken, S.; Song, H.-J.; Park, J.-J. Landfill gas (LFG) processing via adsorption and alkanolamine absorption. Fuel Process. Technol. 2010, 91, 635-640.

91. Gaur, A.; Park, J.-W.; Jang, J.-H. Metal-carbonate formation from ammonia solution by addition of metal salts--An effective method for $\mathrm{CO}_{2}$ capture from landfill gas (LFG). Fuel Process. Technol. 2010, 91, 1500-1504.

92. Miltner, M.; Makaruk, A.; Harasek, M. Application of gas permeation for biogas upgradeoperational experiences of feeding biomethane into the austrian gas grid. In 16th European Biomass Conference \& Exhibition From Research to Industry and Markets, Valencia, Spain, 2008.

93. Ulleberg, Ø.; Nakken, T.; Eté, A. The wind/hydrogen demonstration system at Utsira in Norway: Evaluation of system performance using operational data and updated hydrogen energy system modeling tools. Int. J. Hydrog. Energy 2010, 35, 1841-1852.

94. Prism Membrane Hydrogen Recovery \& Purification. Available online: http://www.airproducts. com/products/Gases/supply-options/prism-membrane-hydrogen-recovery-and-purification.aspx (accessed on 16 October 2012).

95. Brunetti, A.; Bernardo, P.; Drioli, E.; Barbieri, G. Membrane engineering: Progress and potentialities in gas separations. In Membrane Gas Separation; Yampolskii, Y., Freeman, B., Eds.; John Wiley \& Sons, Ltd: Chichester, UK, 2010; pp. 279-312.

96. Naturalhy. Available online: http://www.naturalhy.net/ (accessed on 16 October 2012).

97. Grainger, D.; Hägg, M.-B. The recovery by carbon molecular sieve membranes of hydrogen transmitted in natural gas networks. Int. J. Hydrog. Energy 2008, 33, 2379-2388.

98. Rebollar-Perez, G.; Carretier, E.; Lesage, N.; Moulin, P. Volatile organic compound (VOC) removal by vapor permeation at low voc concentrations: Laboratory scale results and modeling for scale up. Membranes 2011, 1, 80-90.

99. Liu, Y.; Feng, X.; Lawless, D. Separation of gasoline vapor from nitrogen by hollow fiber composite membranes for VOC emission control. J. Membr. Sci. 2006, 271, 114-124.

100. Majumdar, S.; Bhaumik, D.; Sirkar, K.K. Performance of commercial-size plasmapolymerized PDMS-coated hollow fiber modules in removing VOCs from $\mathrm{N}_{2}$ /air. J. Membr. Sci. 2003, 214, 323-330.

101. GKSS Home Page. Available online: http://www.hzg.de/ (accessed on 16 October 2012).

102. MTR Home Page. Available online: http://www.mtrinc.com/ (accessed on 16 October 2012).

103. The OPW Vaporsaver ${ }^{\mathrm{TM}}$ system. Available online: http://www.opwglobal.com/ (accessed on 16 October 2012).

104. Pattle, R.E. Production of electric power by mixing fresh and salt water in the hydroelectric pile.

Nature 1954, 174, 660-660. 
105. Tofte prototype plant. Available online: http://www.statkraft.com/energy-sources/osmoticpower/prototype/ (accessed on 16 October 2012).

106. Gerstandt, K.; Peinemann, K.-V.; Skilhagen, S.E.; Thorsen, T.; Holt, T. Membrane processes in energy supply for an osmotic power plant. Desalination 2008, 224, 64-70.

(C) 2012 by the authors; licensee MDPI, Basel, Switzerland. This article is an open access article distributed under the terms and conditions of the Creative Commons Attribution license (http://creativecommons.org/licenses/by/3.0/). 